\title{
Argument Structure of Transitive Sentence in Toba Batak Language*
}

\author{
Ida Basaria ${ }^{1}$ \\ ${ }^{I}$ Faculty of Cultural Sciences, University of Sumatra Utara, Medan (Indonesia)
}

\begin{abstract}
The objective of the research is to describe the argument structure of transitive sentence (ASTS) in Toba Batak Language (TBL). The data is analyzed by distributional method as suggested by Soedaryanto (1993) and Mahsun (2011). With the use of the oral and written data, as well as the observation method, this research has found that the argument structure of indirect object is placed preceding the verb and argument structure of direct object which becomes the subject itself, is followed by the indirect object. In bi-transitive sentence, there is one oblique argument which is marked by preposition /tu-/. Each of the verb then forms the transitive and bitransitive sentence which are of course marked by different affixes.
\end{abstract}

Keywords: argument, direct object, indirect object, structure, transitive sentence.

\subsection{Background}

\section{Introduction}

According to Warneck, the word "batak" has been derived from the word "mambatak" which means "to slip off horse' in order that it runs quickly. The horse symbolizes the bravery, courage, tenacity and fighting spirit. Long time ago, Batak people used the horse to build their villages in hinterland or when they fought against their enemies. Even in the painting of Sisingamangaraja XII who was known as the King of Batak, he was riding a horse and this can manifest a power of hero. While up to the present time, more people in any hinterland areas in Batak land still ride horses as their transport vehicles. Toba Batak Language (TBL) is one of local languages in North Sumatra Province (Indonesia). TBL is still used by Batak people as their communication language. Generally, TBL has some dialects such as Toba Samosir, Toba Humbang, Toba Silindung, etc. Morphologically, TBL is classified into agglutinative language typology, which is characterised by the use of affixes, for example, the word "mambaen" 'to make' that consists of affix /mam-/ and free morpheme "bahen." Syntactically, the sentence structure of TBL is VOS, which can be seen in example (1):

$$
\begin{aligned}
& \text { Mangalompa indahan inang } \\
& \text { to cook rice mother } \\
& \text { V } \\
& \text { 'Mother cooks rice' }
\end{aligned}
$$

Transitivity is a general issue in all of languages meaning that all languages have transitive or intransitive sentences as well as TBL. This research analyzes the argument structure of transitivity in TBL that is bound by its verb predicate. Furthermore, in the analysis of verb constructions, the affixes which mark each verbal transitive constructions is discussed. O'Grady et.al. (1989:141) argue that the subcategorization frame -[__NP] - indicates that a verb cannot occur with a sister NP (a direct object). Such verbs are often called intransitive. The frame $+[\ldots$ NP], in contrast, indicates that the verb requires a direct object. Such verbs are called transitive. Verbs (such as study) that optionally take a direct object have the subcategorization frame $+[$ _(NP)]. In TBL the verb "mangalompa" 'to cook' in sentence (1) which has a direct object is to have the same subcategorization frame as the verb study in English.

\subsection{Method of Research}

This research is a descriptive and qualitative study. Descriptive does not mean only to provide a description about the transitive sentence in TBL, but also to describe the invention and marking of transitive verb of TBL. Also in this research, the method applied in data analysis is distribution method (see Soedaryanto, 1993:15; Mahsun, 2011:102-142).This research uses the oral and written data. The written data is collected from the written sources such as magazines or books (Bible and Ende 'hymns' in TBL). In addition, the writer also encourages her intuitive power as the native speaker of TBL in completing the available data. The writer also collects the data by using observation method, i.e. by listening directly the use of TBL in communication and writing down the transitive and bi-transitive sentences and analyzing them one by one to find both the argument structure in transitive sentences and also the affix markers of transitive verbs in TBL. 


\section{Theoretical review}

When talking about predicates and arguments Haegeman (1994:39-54) argue ... that the subcategorization frame of a verb, i.e. whether it is transitive or intransitive, etc., is an unexplained primitive property of the grammar, i.e. a property which does not follow from anything else.... whether a verb is transitive or not is not a matter of mere chance; it follows from the type of action or state expressed by the verb, from its meaning. Haegeman gives an example as shown in (2) and (3).

(2) Maigret imitates Poirot.

(3) Maigret stumbled.

The predicate 'imitate' takes two arguments, represented by 'Maigret' and 'Poirot'. She then stresses that predicates that require two arguments are two-place predicates but intransitive verbs correspond to one-place predicates, as displyaed in (3); they take only one argument. Haegeman concludes that the argument structures of the two sentences in (2) and (3) can be represented by arabic numerals as follow.

$\begin{array}{llll}\text { (4a) imitate: } & \text { verb; } & 1 & 2 \\ & & \text { NP } & \text { NP } \\ \text { (4b) stumble } & \text { verb; } & 1 & \\ & & \text { NP } & \end{array}$

Haegeman and Gueron (1999:29-30) has discussed the predicate which is followed by clausal complement which is bracketed and underlined as written in (5). The interpretation of the verb 'believe' is similar to its interpretation in (3) and (4); the difference is that within the complement clause, 'abandoned' assigns two thematic roles: one to Loiuse and one to her husband.

$$
\begin{aligned}
& \text { Thelma believes [that Louise has ababndoned her husband]. } \\
& {\left[\begin{array}{llll} 
& 1 & 2 & ]
\end{array}\right]}
\end{aligned}
$$

Arguments are not the same as complements. Ouhalla (1999:45-46) gives his opinion that verbs are said to subcategorize into various sub-groups, depending on whether they require a complement, and if they do, what type of complement they require. He argues that the subcategorization properties of verbs can be formally represented in terms of frames which are called subcategorization frames, for examples: (i) kick: [V;--NP]; (ii) cry: [V;--]; (iii) rely: [V;--PP]; (iv) put: [V;--NP PP]; and (v) think: [V;--S]. He elaborates that subcategoriztion frames can form the basis on which a general subcategorization rule can be set up which would make rewriting a terminal symbol as a specific lexical item sensitive to the subcategorization properties of the lexical item.

Alsina (1996:149-160) who took data from Roman language said that the structure of argument consists of more than one internal argument in which a clause may have more than one Object $(\mathrm{O})$. The numbers of $\mathrm{O}$ are determined by the type of verbal clauses. Transitive verb, for instance, requires two Os that are traditionally known as Direct Object (DO) and Indirect Object (IO). Based on data in Roman language, Alsina then argued that IO is similar to Oblique (OBL) that is marked by preposition, and the place of IO tends to follow DO. Having different characteristics with DO, the IO does not correspond to Subject (S). Some discussions of O in acrosslanguages is based on the application of some tests to the features of $\mathrm{O}$ in Bantu languages; the results can be seen in Butt, at.al. (1999:48-51) and Jufrizal (2007:51). They conclude that transitive verb has an S and second argument. The second argument is known as $\mathrm{O}$. Below is an example of English transitive sentence with S and O.

$$
\begin{aligned}
& \text { They saw the box } \\
& \text { S PRED O }
\end{aligned}
$$

Butt at.al. (1999) argue that in English the position of sentence elements, for instance, becomes a good determiner in testing its objectivity because the $\mathrm{O}$ must follow verb and is close to the verb. Meanwhile, Alsina (1996:4-7) tends to say that a predicate may have a correlation between participants in a clause. The participant is known as predicate argument. Each predicate (verbal or non-verbal) has logic correspondence with its argument. The correlation of grammatical functions (subject, object, oblique, etc.) with predicate argument is not random or unexpected. Whether the argument is expressed as subject, object, etc. it is determined by predicate semantics. Each verb must be in concordance with its argument. The binding and relation of information within the predicate argument(s) and the predicate itself can automatically form a structure which is then known as argument structure. The argument structure also gives minimal information of predicate that is required to derive its frame of syntax.

Manning (1996:35-36) writes that the meaning of argument structure as previously suggested by Alsina is the manifestation of semantics rather than the syntax. He arguues the grammatical structure and argument structure is a direct result of grammatical process of two different correlations. The predicate of transitive verb 
requires two arguments or more. The presence of these arguments in transitive sentence predicate is obligatory; if the verb is semi transitive, its predicate can have only one argument. The argument structure of transitive verb in TBL is summarized in Table 1 as follows (Basaria, 2011:205).

Table 1 TBL argument structure of transitive verb

\begin{tabular}{|c|c|}
\hline Predicate & Adjunct \\
\hline $\begin{array}{c}\text { Predicate + } \\
\text { Argument (1) (Argument (2)) } \\
(\text { OBJ) } \\
(\text { Semi-transitive) }\end{array}$ & + non argument element \\
\hline $\begin{array}{cc}\text { Predicate }+\underset{(\mathrm{OBJ})}{\text { Argument }}(1) & (\text { Argument }(2)) \\
(\text { Transitive }) & (\text { SUBJ })\end{array}$ & \\
\hline $\begin{array}{c}\text { Predicate }+\underset{\text { Argument (1) }}{\text { (OBJ 1) }} \quad \begin{array}{c}\text { Argument (2) } \\
\text { (Bi-transitive) }\end{array} \\
\text { (OBJ 2) }\end{array}$ & \\
\hline
\end{tabular}

\section{Findings and discussion}

\subsection{Argument structure of transitive sentence in TBL}

A transitive sentence is a verbal sentence in which its object is compulsory to exist. In TBL, there are many transitive verbs which have affixes preceded by nasals. This verbal transitive sentence is productive. Based on its function and category or on its class of element formations, the transitive sentence is divided into the followings.

\subsubsection{The accusative of verbal transitive sentence in TBL}

Causative is an expression in which an event is described as it is happening and this is caused by someone who does anything or by something happens by itself. Not all object arguments in TBL become the first target of transitive verb, for instance, its role stands as object. Instead of its role as recipient (or patient), the object argument has another role as receiver, instrument, target, place and result. The accusative transitive sentence with its object argument as recipient can be seen in Table 2 .

Table 2 The accusative of verbal transitive sentence in TBL

\begin{tabular}{|l|l|l|l|}
\hline Class & VP & IO & NP \\
\hline & V & Object & DO \\
\hline Function & Predicate & Patient & Subject \\
\hline Role & Actor & baju i 'shirt' & Agent \\
\hline 1. & Mangaribak 'tear' & si Rotua 'Rotua' \\
2. & Manggotil 'pinch' & si Poltak 'Poltak' \\
huting i 'the cat' \\
dakdung ' \\
4. & Manerkam 'pounch' & Mangga 'manganger child' \\
\hline Sentence & Causative transitive & & \\
\hline
\end{tabular}

The data above tells us that the affix markers for the accusative of verbal transitive sentence in TBL is marked by /mang-/, /ma-/, and /man-i/

\subsubsection{The receptive of verbal transitive sentence in $T B L$}

The receptive means that the object argument (DO) has role as receptor of action indicated by its verb. Some examples can be seen in Table 3 .

Table 3 The receptive of verbal transitive sentence

\begin{tabular}{|l|l|l|l|}
\hline Class & VP & N & NP \\
\hline & V & IO/ Object & \\
\hline Function & Predicate & Recipient & DO/Subject \\
\hline Role & Actor & penjahat i 'criminal' & Agent \\
\hline 5. & Peluahon 'release' & angka sisean na 'students' & ibana 'his' \\
6. & Manulangi 'feeding' & hasian na 'his lover' \\
7. & Manurati 'write letter' & dakdanak na 'his child' & ina i 'the woman' \\
8. & Manyusui 'breast feeding' & & \\
\hline Sentence & Receptive transitive & & \\
\hline
\end{tabular}

In TBL the affixes which form the receptive of verbal transitive sentence are /pa-hon/ and /ma-i/.

\subsubsection{The locative of verbal transitive sentence in $T B L$}

In verbal transitive sentence, its object argument (IO) has a semantic role as 'locative' that receives the action as indicated by the verb which becomes the core in the sentence. See the examples in Table 4. 
Table 4 The locative of verbal transitive sentence

\begin{tabular}{|l|l|l|l|}
\hline Class & VP & NP \\
\hline & V & N & N \\
\hline Function & Predicate & IO/Object & DO/Subject \\
\hline Role & Actor & Locative & Agent \\
\hline 9. & Manganakkohi 'to climb up' & $\begin{array}{l}\text { dolok 'mountain' } \\
\text { jabuna 'his house' }\end{array}$ & $\begin{array}{l}\text { hami 'us' } \\
\text { tuturna 'his guest' }\end{array}$ \\
\hline 10. & Manggaohi 'to fulfill' & & \\
\hline Sentence & Locative transitive & & \\
\hline
\end{tabular}

All arguments in the sentences in Table 4 have roles as 'places' but not 'recipients'. The characteristics of locative in transitive sentence are marked by the affixes attached to the verbs such as /ma-i/ and /mang-i/. These affixes do not appear if the sentence (9), for example, is changed into "Hami nakko tu dolok" "we climb up the mountain'.

\subsubsection{The resultative of verbal transitive sentence in TBL}

The sentences in (11) to (14) are well known as the resultative of transitive sentences because their object arguments indicate the 'results' of the action performed by the verbs. Their subject arguments have roles as 'doer' of the action. Consider the examples in Table 5 showing some prefixes, for instance, /ma-/, /mang-/, /man-/, and /mam-/, which are added to the verbs.

Table 5 The resultative of verbal transitive sentence in TBL

\begin{tabular}{|l|l|l|l|}
\hline Class & VP & N & NP \\
\hline & V & IO/Object & DO/Subject \\
\hline Function & Predicate & Resultative & Agent \\
\hline Role & Actor & surat 'letter' & ompung 'grandfather' \\
dalan 'road' & halaki 'them' \\
11. & Manurat 'to write' & tulang 'uncle' \\
12. & Mangaspal 'to pave' & inong 'mother' \\
13. & Mencetak 'to print' & sipanganon 'food' & \\
14. & Mambahen 'to make' & & \\
\hline Sentence & Resultative transitive & & \\
\hline
\end{tabular}

\subsubsection{The negative causative of verbal transitive sentence in $T B L$}

The object arguments of the sentences in (15) to (17) are IO and have the roles as negative causative as the consequences of events done by subject arguments. Some affix markers for negative causative are /manghon/, /ma-i/ and /manga-i/ as displayed in Table 6.

Table 6 Negative causative of verbal transitive sentence

\begin{tabular}{|l|l|l|l|}
\hline Class & VP & $\mathrm{N}$ & $\mathrm{NP}$ \\
\hline & $\mathrm{V}$ & IO/Object & DO/Subject \\
\hline Function & Predicate & Consequence & Agent \\
\hline Role & Actor & $\begin{array}{l}\text { hosania 'our soul ' } \\
\text { kota 'city' } \\
\text { pikkiran 'mind' }\end{array}$ & $\begin{array}{l}\text { dosa i 'the sin' } \\
\text { halisungsung i 'storm' } \\
\text { si bolisi 'evil }\end{array}$ \\
$\begin{array}{l}15 . \\
17 .\end{array}$ & $\begin{array}{l}\text { Manghancurhon 'to destroy' } \\
\text { Mangarasuni 'to poison' }\end{array}$ & & \\
\hline Sentence & Causative transitive & & \\
\hline
\end{tabular}

\subsubsection{The positive causative of verbal transitive sentence in TBL}

The verbal transitive sentences as written in (18)-(21) in Table 7 consist of the IO arguments which function as positive causative and this is caused by their subject arguments. Therefore, these sentences are considered positive causative of transitive sentences. The affix marker of /pa-hon/ is conjoined to the verbs while the subject arguments (DO) or the object arguments are determined by the lexical meaning of the verbs in which the verbs are the core.

Table 7 The positive causative of verbal transitive sentence in TBL

\begin{tabular}{|l|l|l|l|}
\hline Class & VP & N & NP \\
\hline & V & IO/Object & DO/Subject \\
\hline Function & Predicate & Consequence & Agent \\
\hline Role & Actor & $\begin{array}{l}\text { huria 'church' } \\
\text { hamatean 'death' } \\
18 .\end{array}$ & Pabagakhon 'to decorate' \\
19. & Pahatophon 'to accelerate' & Paulihon 'to beautify' & $\begin{array}{l}\text { lukisanpi 'the painting' } \\
\text { dosa i 'the sin' } \\
\text { anakboru i 'the lady' }\end{array}$ \\
\hline
\end{tabular}




\begin{tabular}{|l|l|l|l|}
\hline 21. & Paubahon 'to change' & pangalahonta 'our behavior' & pandita i 'the priest' \\
\hline Sentence & Positive causative transitive & & \\
\hline
\end{tabular}

In Table 7, the IO has the role as receptor of positive causative which is based on the lexical meaning of the verb. Some other examples of the use of affix /pa-hon/ can be seen in Table 8 snd in (7) to (9) in which the subject argument (IO) is not only the causal but also the doer.

Table 8 The negative causative of verbal transitive sentence with afix /pa-hon/

\begin{tabular}{|c|c|c|c|}
\hline Class & VP & & NP \\
\hline & $\mathrm{V}$ & $\mathrm{N}$ & \\
\hline Function & Predicate & IO/Object & DO/Subject \\
\hline Role & Actor & Consequence & Agent \\
\hline $\begin{array}{l}22 . \\
23 . \\
24 . \\
25 .\end{array}$ & $\begin{array}{l}\text { Pasusahon 'to complicate' } \\
\text { Patajomhon 'to sharp' } \\
\text { Pasingkophon 'to perfect' } \\
\text { Paroahon 'to make bad' }\end{array}$ & $\begin{array}{l}\text { doingan na 'his friend' } \\
\text { parsoalan 'problem' } \\
\text { pardalanan 'journey' } \\
\text { hadirion 'image' }\end{array}$ & $\begin{array}{l}\text { pangalahona 'his attitude' } \\
\text { pandapat i 'opinion' } \\
\text { siseanna i 'his student' } \\
\text { haotoan 'stupidness' }\end{array}$ \\
\hline Sentence & $\begin{array}{l}\text { Negative causative transitive with } \\
\text { /pa-hon/ }\end{array}$ & & \\
\hline
\end{tabular}

(7) Mamparsusa parsingkola guru i

$$
\mathrm{V} \quad \mathrm{IO} \quad \text { DO }
$$

'teacher complicates the student'

(8) Mamparipe Minah si Roni

$$
\text { V IO DO }
$$

propose Minah (by) Roni

'Roni is married to Minah'

(9) Papistarhon pinompar halak Batak

$$
\mathrm{V} \quad \mathrm{IO} \quad \mathrm{DO}
$$

educate descendant people Batak

'The people of Batak educate their descendants'

Furthermore, the positive causative of verbal transitive sentence is also marked by verbal affixes

\begin{tabular}{|c|c|c|c|}
\hline Class & \multicolumn{2}{|l|}{ VP } & $\mathrm{NP}$ \\
\hline & $\mathrm{V}$ & $\mathrm{N}$ & \\
\hline Function & Predicate & IO/Object & DO/Subject \\
\hline Role & Actor & Patient & Agent \\
\hline $\begin{array}{l}26 . \\
27 . \\
28 . \\
29 .\end{array}$ & $\begin{array}{l}\text { Mampartaruhon 'entrust' } \\
\text { Mampartahanhon 'to maintain' } \\
\text { Mamparsadahon 'to unify } \\
\text { Mamparohahon 'to pay attention' }\end{array}$ & $\begin{array}{l}\text { hosa 'soul' } \\
\text { sinamot 'brideprice } \\
\text { angka naporsea 'the faith people' } \\
\text { dakdanaki 'the child' }\end{array}$ & $\begin{array}{l}\text { Tuhan i 'the God' } \\
\text { nasida 'them' } \\
\text { ibana 'him/her' } \\
\text { ibana 'him/her' }\end{array}$ \\
\hline Sentence & Positive causative transitive & & \\
\hline
\end{tabular}
/mampar-hon/ as shown in Table 9.

Table 9 The positive causative of verbal transitive sentence with verbal affix mampar-hon

\subsection{Bi-transitive verbal sentence}

Van Valin, Jr and LaPolla (1999:148-150) say that the verb with one core argument in syntax is known as intransitive verb and the verb with two arguments is known as bi-transitive and verb with three arguments is known as three-transitive. Object is argument that undertakes the action indicated by transitive verb. The direct object (DO) and indirect object (IO) must appear simultaneously on clause with bi-transitive verb. IO in TBL is Noun Phrase(NP) in the center part position directly preceding the verb, while DO follow it. Both DO and IO may be the subject of passive sentence (by passive process). The relation of oblique (OBL) is addressed to the group of non subject argument and this OBL has the morpho-syntactic form which is not suitable to be the object. The oblique does not undergo syntactic process that can influence the passivization. Generally, oblique is a prepositional phrase (Butt et.al. 1999:50). In English, for example, prepositional phrase (PP) 'to him' in (10) and (11) can be categorized as OBL rather than as IO because the PP does not involve passive process.

(10) She gave the book to him

(11) The books was given to him 


\subsubsection{The receptive-accusative of verbal bi-transitive sentence in TBL}

The sentence "mangalului parkarejoan tulang tu au" '(my) uncle seeks a job for me' requires two nominal arguments, such as "parkarejoan" 'job' and "tulang" 'uncle' following their predicate. Both nominals are compulsory to exist and have close correlation and they cannot be separated. Therefore, the sentences in (12) to (13) are known as bi-transitive sentences. In this research, the argument "parkarejoan" is known as IO and "tulang" as DO and as subject while "tu au" is an oblique relation (OBL). This oblique relation does not have not a role in passive process (Fokker, 1976:22-24). In TBL, OBL relation is indicated by preposition "tu" 'to'. In passivization the IO in TBL can function as subject of passive sentence as written in (12) and (13).

$$
\text { Mangalului parkarejoan tulang tu au }
$$

$\begin{array}{cccc}\text { V } & \text { IO } & \text { DO } & \text { OBL } \\ \text { seek } & \text { job } & \text { uncle } & \text { for me }\end{array}$

'My uncle seeks a job for me.'

Parkarejoan dilului tulang tu au

$$
\text { IO } \quad \mathrm{V} \text { DO OBL }
$$

'Uncle seeks a job for me'

Table 10 The receptive-accusative of bi-transitive sentence

\begin{tabular}{|l|l|l|l|l|}
\hline Class & VP & & NP \\
\hline & VP & N & N \\
\hline & V & IO & DO/Subject \\
\hline Function & Predicate & OBL & Patient & Agent \\
\hline Role & Actor & Recipient & $\begin{array}{l}\text { bapa 'father' } \\
\text { biblevrouwi 'the bible mother' } \\
\text { partani i 'the farmer' } \\
\text { pandita i 'the priest' }\end{array}$ \\
\hline 30. & $\begin{array}{l}\text { Manongosi 'to send' } \\
\text { Mangajari 'to teach' } \\
32 .\end{array}$ & $\begin{array}{l}\text { au 'me' } \\
\text { nasida 'them' } \\
\text { anakna 'his child' } \\
\text { au 'me' }\end{array}$ & $\begin{array}{l}\text { 'mathemathics' } \\
\text { bukku 'my book' } \\
\text { parkarejoan 'job' }\end{array}$ & \\
\hline Cohesion & & Bi-transitive & & \\
\hline
\end{tabular}

Based on the above examples, it can be concluded that in TBL the affix markera of the receptiveaccusative of verbal bi-transitive sentence are /ma-i/ and /ma-hon/. The OBL argument of bi-transitive sentence has the same pattern as shown to the above examples in Table 10 and in (14) to (15) below and it has role as recipient and the DO argument becomes the doer. If suffix $-\mathrm{i}$ / in bi-transitive sentence has a derived verb that is formed by a combination of affix /mo-i/ is removed, what happens then is the shifting of the element of OBL "au" to the position following the DO.

(14)a. manongosi au hepeng bapa

$$
\text { V OBL IO DO }
$$

'to send me money father'

b. manongos hepeng bapa tu au

$$
\mathrm{V} \text { IO DO OBL }
$$

'to send money father to me'

(15) a. Mangajari nasida marende biblevrou i

$$
\mathrm{V} \text { OBL IO DO }
$$

'The bible mother teaches them sing'

b. mangajar marende biblevrou to nasida

$$
\mathrm{V} \text { IO DO OBL }
$$

'The bible mother teaches singing for them'

\subsubsection{The locative instrumental of verbal bi-transitive sentence}

In the sentences (34)-(38) in Table 11 there are two type of arguments. The first argument has a function as direct object (DO) with its role to show 'instrument' which is used to do an action as indicated by the predicate and the second one has function as oblique (OBL) as denoted by preposition 'tu" 'to' that shows the 'object of action'. The IO and OBL are absolute.

Table 11 Locative instrumental of bi-transitive verbal sentence

\begin{tabular}{|l|l|l|l|l|}
\hline Function & Predicate & IO & OBL & DO/Subject \\
\hline Role & Actor & Instrument & Target of location & Agent \\
\hline 34. & $\begin{array}{l}\text { Manembakhon 'to shot' } \\
\text { 35. }\end{array}$ & $\begin{array}{l}\text { pistol 'pistol' } \\
\text { tali 'rope' } \\
\text { balati 'knife' } \\
\text { Manusukhon 'to prick' }\end{array}$ & $\begin{array}{l}\text { toi alogo 'to alogo' } \\
\text { toi hau i 'to the wood' } \\
\text { to horbo i 'to the buffalo' } \\
\text { toi bondar i 'to the ditch' }\end{array}$ & $\begin{array}{l}\text { polisi 'police' } \\
\text { tulang 'uncle } \\
\text { si Ucok 'Ucok' } \\
\text { panakkoi 'the thief' }\end{array}$ \\
\hline
\end{tabular}




\begin{tabular}{|l|l|l|l|l|}
\hline $\begin{array}{l}37 . \\
38 .\end{array}$ & Manganggurhon 'to throw' & batu 'stone' & & \\
\hline
\end{tabular}

When suffix /-hon/ is removed, the construction of sentences can be seen as examples in (16-(19).

$$
\begin{aligned}
& \text { manembak alogo polisi dohot pistol } \\
& \mathrm{V} \text { IO DO OBL } \\
& \text { 'police shoots to the air by pistol' } \\
& \text { mangikat rungkung (hambingi) tulang dohot tali } \\
& \mathrm{V} \quad \mathrm{IO} \quad \mathrm{DO} \text { OBL }
\end{aligned}
$$

'The uncle ties the neck of the goat witha rope'

manusuk butuha (panakkoi) si Ucok dohot balati

$$
\mathrm{V} \text { IO DO OBL }
$$

'Ucok stabs the belly of the thief with a knife'

manikkam andora (buruanna) pabburu i dohot tombak

$$
\mathrm{V} \text { IO DO OBL }
$$

'The hunter stabs the chest of his hunted animal with a spear'

The omission of suffix /hon-/ changes the syntactic structure of the sentence in which the OBL moves to the last position after the DO argument

\begin{tabular}{|c|c|c|c|c|}
\hline Function & Predicate & DO & OBL & IO/Subject \\
\hline Role & Actor & Instrument & Target of location & Agent \\
\hline Cohesion & $\mathrm{V}$ & $\mathrm{N}$ & $\mathrm{PP}$ & $\mathrm{N}$ \\
\hline $\begin{array}{l}39 . \\
40 . \\
41 . \\
42 .\end{array}$ & $\begin{array}{l}\text { Mangaletakhon 'to put' } \\
\text { Manaruhon 'to deliver' } \\
\text { Pemasukhon 'to put into' } \\
\text { Pakaluarhon 'to take out' }\end{array}$ & $\begin{array}{l}\text { jimat 'amulet' } \\
\text { nasida 'them' } \\
\text { hepeng 'money' } \\
\text { tahanan 'prisoner' }\end{array}$ & $\begin{array}{l}\text { di rungkun na 'in neck' } \\
\text { tujabu na 'to his house' } \\
\text { sian hurungan 'prison } \\
\text { 'tulamari 'to the cupboard' }\end{array}$ & $\begin{array}{l}\text { si Jakob 'Jakob' } \\
\text { hami 'us' } \\
\text { bapa 'father' } \\
\text { polisi 'police' }\end{array}$ \\
\hline
\end{tabular}

\subsubsection{Locative Receptive of Bi-transitive Verbal Sentence}

All sentences in (39)-(42) have the DO argument which have function as instrument or receptor of the action performed by its IO argument. The oblique (OBL) has function to indicate the target of place/location and becomes the PP of the verb; this PP is compulsory and when it is removed, the sentence is not less complete. In TBL, the affix markers of the locative receptive of bi-transitive sentence are /ma-hon/ and /pa-hon/.

Table 12 The locative receptive of verbal bi-transitive sentence

\section{Conclusion}

The argument structures which forms the transitive sentence in TBL are the DO which stands behind the verb and the IO which becomes the subject argument and follows the DO. The transitive sentence in TBL owns OBL argument that is characterized by preposition tu-, as well as the DO and the IO arguments. Each verb that forms the transitive sentence is marked by different affix. In accusative transitive sentence, the verb is known by the use of affix /mang-, ma and man-i/; in receptive transitive sentence, it is labelled by /pa-hon/ and /ma-io/; the verb of locative transitive is distinguished by affix /ma-i/ and /mang-i/; the verb of resultative transitive sentence is indicated by affix /ma-/, /mang-/, /man-/ and /mam-/; verb of negative causative transitive is branded by affix /mang-hon/, /ma-i/ and /manga-i/; the verb of positive transitive sentence is remarked by /pa-hon/ and /maparhon/. In receptive accusative of bi-transitive sentence the verb is shown by affix /ma-i/ and /ma-hon/' while in locative instrumental of bi-transitive sentence, the verb is stigmatised by affix /ma-hon/; in receptive locative of bi-transitive sentence the verb is noted by affix /ma-hon/ and /pa-hon/.

\section{References}

[1] W. O’Grady, M. Dobrovolsky, and M. Aronoff, Contemporary Linguistics: An Introduction (New York: St. Martin's Press, 1989).

[2] Soedaryanto, Metode dan Aneka Teknik Analisis Bahasa: Pengantar Penelitian Wahana Kebudayaan Secara Linguistik. Yogyakarta: Duta Wacana University Press, 1993).

[3] Mahsun,,MetodePenelitian Bahasa: Tahapan Strategi, Metode danTekniknya (Jakarta: Rajawali Press, 2011).

[4] L. Haegeman, Introduction to Goverment and Binding Theory. 2nd Ed., (Massachusettes: Blackwell, 1994).

[5] L. Haegemen and J. Geuron, English Grammar: A generative Perspective, (Massachusettes: Blackwell, 1999).

[6] J. Ouhalla. Introducing Transformational Grammar: From Principles and Parameters to Minimalism, (New York: Arnold, 1999).

[7] A. Alsina, The Role of Argument Structure in Grammar: Evidence from Romance,(Stanford, California: CSLI Publishers, 1996).

[8] Jufrizal, Diatesis Bahasa Minangkabau, doctoral diss., Padang: Department of English Language and Literature, FBSS, State University of Padang, 2004.

[9] M. Butt, T.H. King, M.E. Nino, F. Segond, A Grammar Writers' Cookbook. (Stanford, California: CSLI Publishers, 1999).

[10] C.D. Manning, Ergativity: Argument Structure and Grammatical Relations. (Stanford, California: CSLI Publications, 1996).

[11] I. Basaria, Relasi dan Peran Gramatilkal Bahasa Pakpak Dairi: Kajian Tipologi Gramatikal, doctoral diss., Medan: Program Doktor Linguistik Universitas Sumatera Utara, 2011).

[12] R.D. Van Valin Jr., R.J. La Polla, 1999. Syntax: Structure, Meaning, and Function. (Cambridge: Cambridge University Press, 1999). 
* My thanks are especially addressed to Muhammad Ali Pawiro who has worked hard to edit from the first to the final draft of this article and has given some suggestions. 